\title{
Origin of mantle-derived carbonate nodules from the Bultfontein kimberlite
}

\author{
Geoffrey H. Howarth ${ }^{1}$, Andy Moore ${ }^{2}$, and Chris Harris ${ }^{1}$ \\ ${ }^{1}$ University of Cape Town, Cape Town, South Africa, geoffrey.howarth@uct.ac.za, chris.harris@uct.ac.za \\ ${ }^{2}$ Rhodes University, Grahamstown, South Africa, andy.moore.bots@googlemail.com
}

\section{Introduction}

In order to account for $\mathrm{CO}_{2}$-rich, Si-undersaturated magmas such as carbonatites and kimberlites, it has long been suggested that a carbonate-bearing peridotite mantle source must be present in the upper mantle. Experimental evidence suggests that if carbonate was present within kimberlite-derived mantle xenoliths, it would dissociate and degass and should not survive transport from the sub-continental lithospheric mantle (SCLM) to the surface (Canil, 1990). However, several studies have described the presence of fine-grained $(10-20 \mu \mathrm{m})$ mantle-derived carbonate within xenoliths (e.g., Berg, 1986). This suggests that in some cases carbonate may survive rapid transport to the surface during kimberlite ascent. Here, we present textural descriptions along with major and trace element, O-C stable isotope, and $\mathrm{Sr}-\mathrm{Nd}-\mathrm{Pb}$ radiogenic isotope data for coarse $(>1 \mathrm{~cm})$ carbonate nodules from the Bultfontein kimberlite, South Africa.

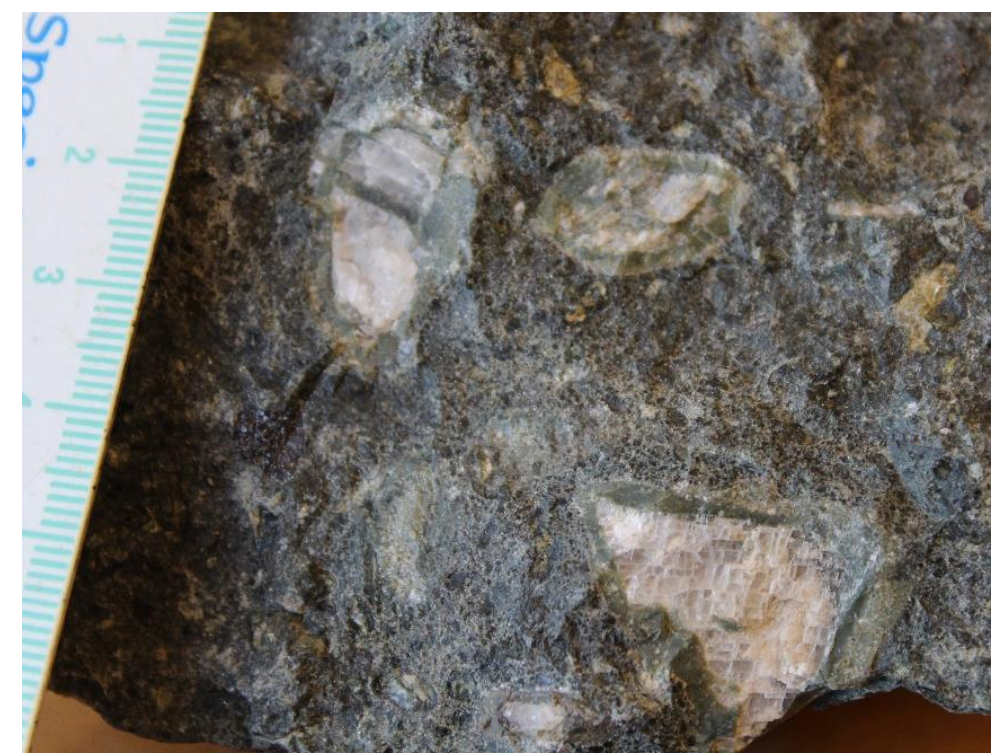

Figure 1. Photograph of carbonate nodules within a hypabyssal kimberlite block from the Bultfontein kimberlite. Note the distinct green reaction margins. Scale is in $\mathrm{cm}$.

\section{Results}

The Bultfontein carbnate nodules (Figure 1) are polycrystalline calcite, coarse-grained $(\sim 4 \mathrm{~mm})$, and are observed up to $10 \mathrm{~cm}$ (Figure 2). They are characterized by reaction margins with quench-related textures, including: radiating clusters of microlitic grains, a glass phase, and spherulites contained within the glass (Figure 2c). Furthermore, olivine grains spatially associated with the carbonate nodules are completely altered relative to the fresh grains away from the margins. Six of the carbonate nodules were powdered and analysed for Sr-Nd$\mathrm{Pb}-\mathrm{O}-\mathrm{C}$ isotopes and solution ICPMS trace element analyses at the University of Cape Town. Strontium and $\mathrm{Ba}$ concentrations are 225-490

ppm and 1.4-17.7 ppm, repsectively. The REE are LREE enriched with relatively low concentraions 0.01 (HREE) to 1 (LREE) relative to chondrite (Figure 3). They have $\delta^{13} \mathrm{C}$ and $\delta^{18} \mathrm{O}$ of -6.0 to $-6.3 \%$ and 15.7 to $16.9 \%$, respectively. The $\left({ }^{87} \mathrm{Sr} /{ }^{86} \mathrm{Sr}\right)_{\mathrm{i}}$ values have little variation with a range of $0.7047-$ 0.7048 (Figure 4). In contrast, a large range in $\mathrm{ENd}$ was obsevered from -3 to -25 (Figure 4). Lead isotopes also show a large range with ${ }^{208} \mathrm{~Pb} /{ }^{204} \mathrm{~Pb}(36.5-38.5),{ }^{207} \mathrm{~Pb} /{ }^{204} \mathrm{~Pb}(15.4-15.6)$, and ${ }^{206} \mathrm{~Pb} /{ }^{204} \mathrm{~Pb}$ (16.7-18.9). 

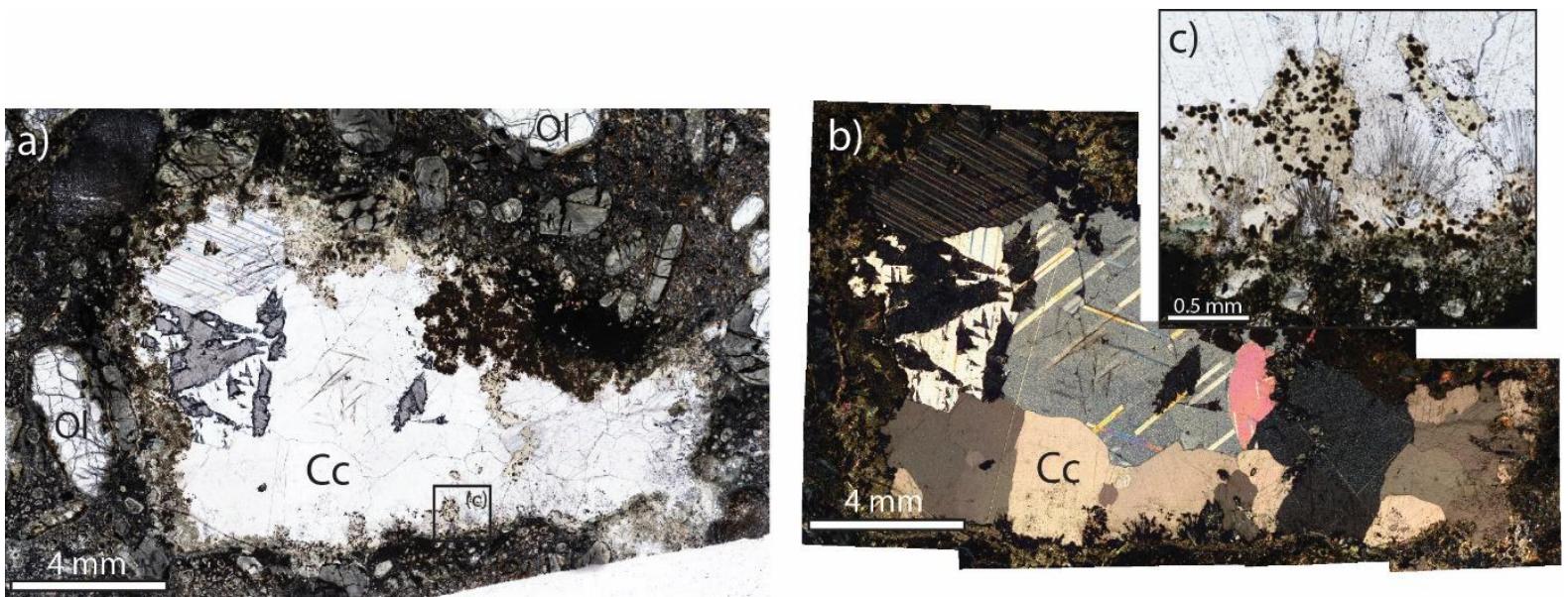

Figure 2. a) Plain polarized light (PPL) and b) cross-polarized light (XPL) photomicrographs illustrating the textures of a representative carbonate nodule from the Bultfontein kimberlite, South Africa. c) Inset: PPL image of the region marked in (a) illustrating the reaction textures surrounding carbonate nodules.

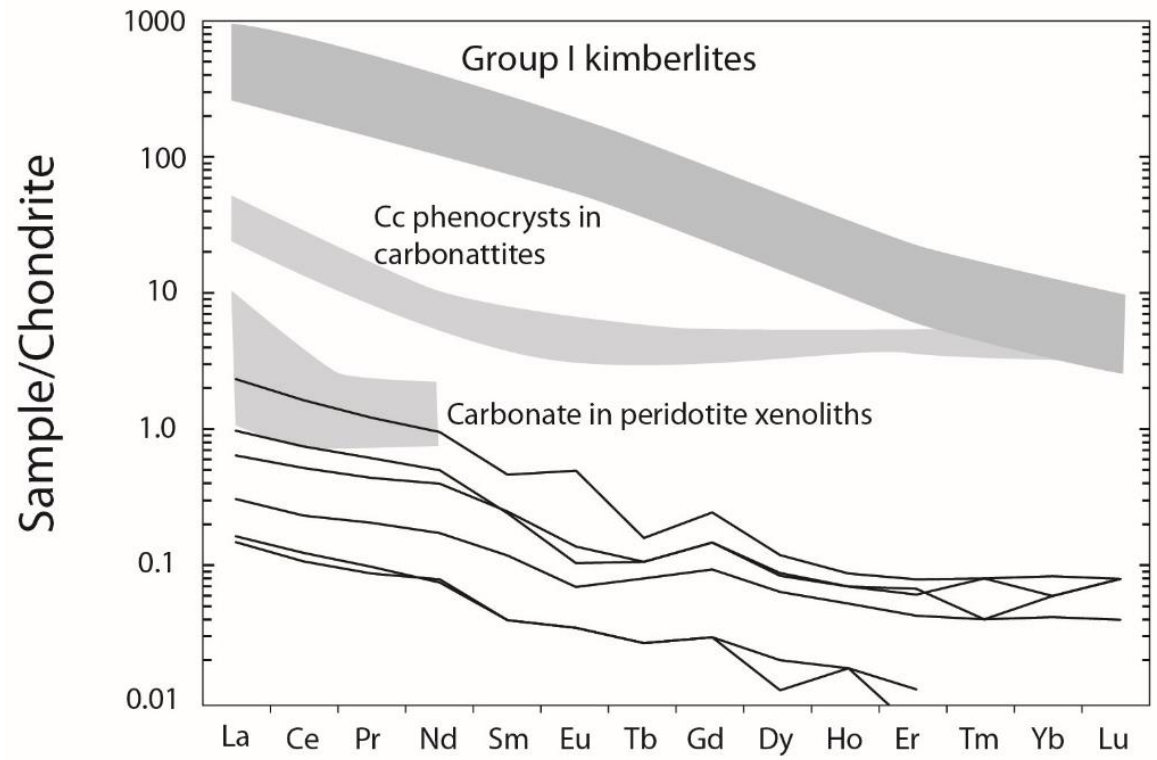

Figure 3. Chondrite normalized REE patterns for the Benfontein carbonate nodules. Field for Group I kimberlites is after Becker and le Roex (2006). The calcite $(\mathrm{Cc})$ phenocryst field is after LREE enriched phenocrysts from the Spitskop carbonattites (Ionov and Harmer, 2002). The field for carboante in peridotite xenoliths is for mantle xenoliths in alkali basalts (Ionov, 1998).

\section{Discussion}

The distinct reaction margins and coarsegrained texture (relative to surrounding groundmass minerals) of the Bultfontein carbonate nodules indicate that they are not late-stage crystallization products but rather represent xenoliths entrained at some stage during kimberlite ascent from the SCLM. The $\delta^{13} \mathrm{C}$ and $\left.\left({ }^{87} \mathrm{Sr} /{ }^{86} \mathrm{Sr}\right)\right)_{\mathrm{i}}$ and are consistent with formation within the mantle and not a crustal component. The REE concentrations are significanlty lower than typical kimberlites

(Figure 3) suggesting that these carbonates do not represent late-stage residual carbonatitic melts associated with kimberlite melt evolution. The REE concentrations overlap with those reported for carbonates from peridotite mantle xenoliths recovered from alkali basalts (Figure 3). The very low ${ }^{143} \mathrm{Nd} /{ }^{144} \mathrm{Nd}$ ratios similarly suggest that these xenoliths are not related to the kimberlite magmas. Additionally the absence of correlation between ${ }^{87} \mathrm{Sr} /{ }^{86} \mathrm{Sr}$ with ${ }^{143} \mathrm{Nd} /{ }^{144} \mathrm{Nd}$ suggests that the very low $\mathrm{ENd}$ is not a result of crustal assimilation, but likely represents an ancient lithospheric mantle source. 


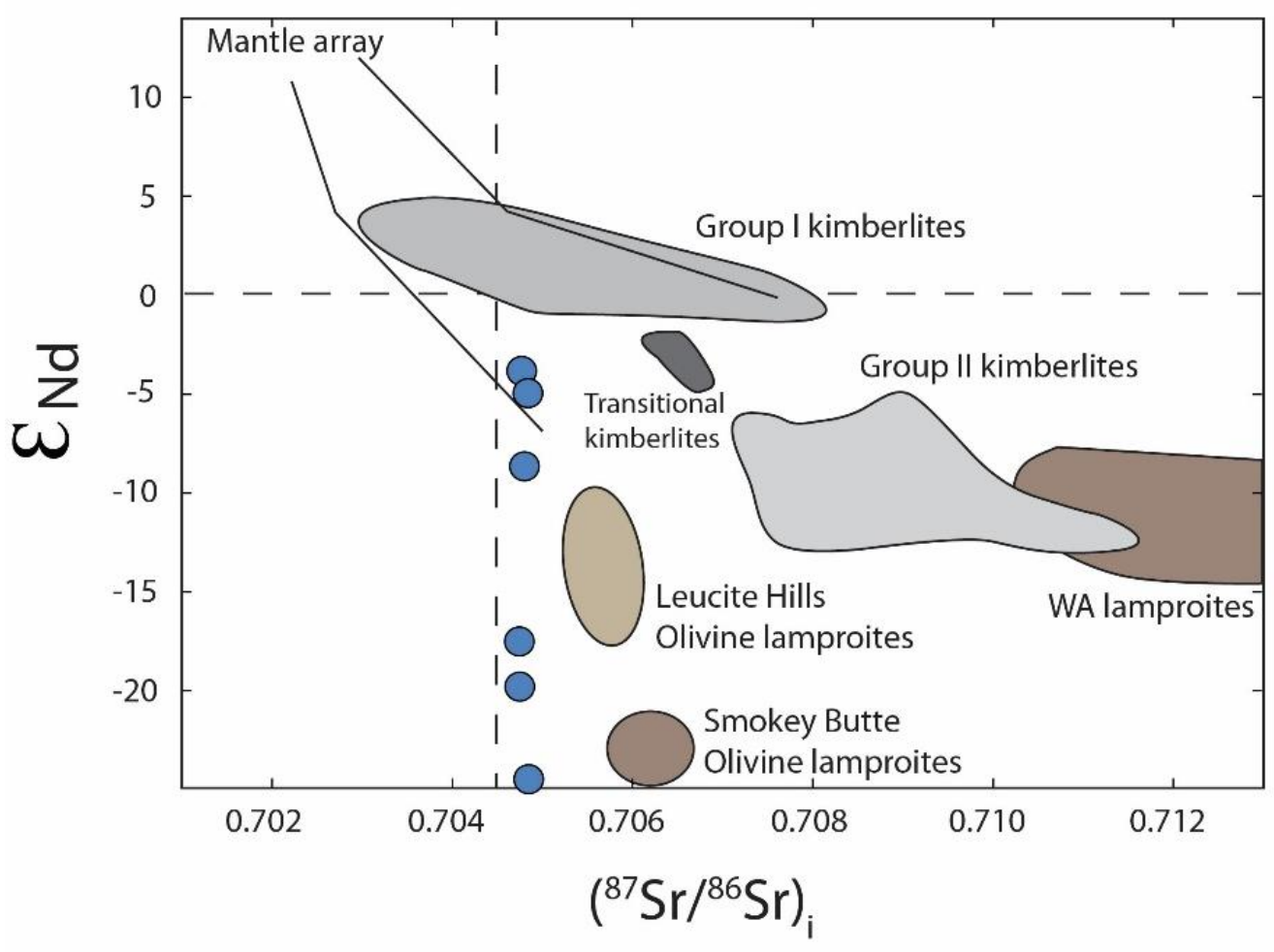

Figure 3. $\left({ }^{87} \mathrm{Sr} /{ }^{86} \mathrm{Sr}\right)_{\mathrm{i}}$ versus $\mathrm{ENd}$ for the Bultfontein carbonate nodules illustrating the large range in $\mathrm{ENd}$ at constant $\left({ }^{87} \mathrm{Sr} /{ }^{86} \mathrm{Sr}\right)_{\mathrm{i}}$. Group I and II kimberlite fields are after Nowell et al. (2004). Lamproite fields are after Fraser et al. (1985).

\section{Conclusions}

Carbonate nodules from the Bultfontein kimberlite represent mantle xenoliths likely derived from an ancient lithospheric mantle source. They do not appear to be related to the host kimberlite. These types of xenoliths have not been previously identified in kimberlite magmas and may represent a distinct coarse-grained carbonate-rich mantle lithology wihtin the SCLM.

\section{References}

Becker, M., \& Le Roex, A. P. (2006). Geochemistry of South African on-and off-craton, Group I and Group II kimberlites: petrogenesis and source region evolution. Journal of Petrology, 47(4), 673-703.

Berg, G. W. (1986). Evidence for carbonate in the mantle. Nature, 324(6092), 50-51.

Canil, D., \& Scarfe, C. M. (1990). Phase relations in peridotite+ CO2 systems to 12 GPa: implications for the origin of kimberlite and carbonate stability in the Earth's upper mantle. Journal of Geophysical Research: Solid Earth, 95(B10), 15805-15816.

Fraser, K. J., Hawkesworth, C. J., Erlank, A. J., Mitchell, R. H., \& Scott-Smith, B. H. (1985). Sr, Nd and Pb isotope and minor element geochemistry of lamproites and kimberlites. Earth and Planetary Science Letters, 76(12), 57-70.

Ionov, D., \& Harmer, R. E. (2002). Trace element distribution in calcite-dolomite carbonatites from Spitskop: inferences for differentiation of carbonatite magmas and the origin of carbonates in mantle xenoliths. Earth and Planetary Science Letters, 198(3), 495-510.

Ionov, D. (1998). Trace element composition of mantle-derived carbonates and coexisting phasesin peridotite xenoliths from alkali basalts. Journal of Petrology, 39(11-12), 1931-1941.

Nowell, G. M., Pearson, D. G., Bell, D. R., Carlson, R. W., Smith, C. B., Kempton, P. D., \& Noble, S. R. (2004). Hf isotope systematics of kimberlites and their megacrysts: new constraints on their source regions. Journal of Petrology, 45(8), 1583-1612. 